\title{
ORIGINS AND EVOLUTION OF INDIAN CINEMA: A CALEIDOSCOPIC VISION OF INDIA
}

\author{
Carmen Escobedo de Tapia \\ Universidad de Oviedo
}

\begin{abstract}
The Western image of India has traditionally been based on the attraction of stereotypes like the exotic, the mystical or the spiritual; if this imaginative construct is evident in literature, with examples like Paul Scott's The Jewel in The Crown and E.M. Forster's A Passage to India. I suggest that this recreation could also be applicable to cinema through stereotypical visions that originally appear in films about India. In this article I aim to explain the evolution of Indian cinema as a genre of its own, using postcolonial concepts like 'mimicry', 'hybridity' or 'liminality' discussed by H.K. Bhabha in The Location of Culture (1994), and through the threefold perspective developed by Priyamvada Gopal in The Indian English Novel: Nation, History and Narration (2009).
\end{abstract}

Keywords: Indian Cinema, Postcolonial Studies, Cultural Studies, Bollywood, Film Studies.

\section{ORÍGENES Y EVOLUCIÓN DEL CINE INDIO: UNA VISIÓN CALEIDOSCÓPICA DE INDIA}

\section{RESUMEN}

La imagen de India que tradicionalmente ha ofrecido occidente está basada en una atracción hacia estereotipos como lo exótico, lo místico o lo spiritual; si esto es evidente en ejemplos dentro del ámbito de la literatura, como La joya de la corona de Paul Scott o Pasaje a la India de E.M. Forster se puede aplicar al ámbito del cine a través de imágenes estereotipadas que aparecen originalmente en las películas sobre India. En este artículo ofrezco una explicación panorámica de la evolución del cine indio como género en sí mismo, utilizando los conceptos poscoloniales de mimicry, hybridity o liminality que H.K. Bhabha desarrolla en The Location of Culture (1994), y utilizando la triple perspectiva que Priyamvada Gopal explica e ilustra en The Indian English Novel: Nation, History and Narration (2009).

Palabras Clave: cine indio, estudios poscoloniales, estudios culturales, Bollywood, estudios sobre cine.

DOI: https://doi.org/10.25145/j.recaesin.2021.83.02 


\section{INTRODUCTION}

Indian literary and cinematographic narratives should be considered artistic representations that clearly show the progress of the Indian historical context where "the idea of India" (Kilkani 1994) is framed, offered by literary authors and film directors. Underlying both narrative discourses, the main concepts discussed by Homi Bhabha in The Location of Culture (1994) are clearly identified. Thus, mimicry, interstice, hybridity, and liminality inevitably characterise the cinema produced in India as a cultural production that reflects, in the most prolific way, the ambivalence inherent to Indian cinematographic paradigms from its origins to the contemporary. In this line I should also consider the importance of the historical and social contexts where the development of Indian cinema takes place. Although it is indispensable to refer to a parallel evolution of both the literary and the cinematographic phenomena, and take into consideration that several novels have been and are being adapted into films, there is no question about the fact that the Indian cinema in its evolution has acquired specific characteristics that allow us to talk about an independent genre. As said, both artistic fields intermingle due to the nature of the Indian context and its historical progress. This is where the threefold approach -history, nation and narration (Bhabha 1990; Gopal 2009) - required to interpret and understand the literary texts also acquires significance and relevance in the field of Indian cinema. It is within this referential framework where the view I aim to propose is based.

When approaching the cultural context of the Indian subcontinent, an important synthetic exercise should be done. The threefold perspective previously mentioned should be considered when analysing any cultural construct which represents what political scientist Sunil Kulkani termed "the idea of India", a diverse, heterogenous and complex entity as well as still a fairly distant and unknown context in the western part of the world, both geographically and culturally.

It is for this reason that I have structured this article tackling the social and the historical aspects that are inherent to the evolution of the cinema in India, which also goes parallel to the evolution of the literary, most specifically the narrative genres. It can be stated that both fields start their firm pace towards the contemporary in the 1930s, and more specifically after the Independence in $1947 .{ }^{1}$

Taking the historical development as the chronological point of departure of the development of Indian narratives in English helps us to shed light onto the sphere of the cinematic production of India, which is considered among the so-called 'other cinemas' or 'cinema of other countries', with the marginality implied in these terms. It is at this point that the Indian cinema relates to the postcolonial discourse being characterized by concepts explained by Homi K. Bhabha in The Location of Culture (1994). The fact that the colonial discourse accepts and negates any cultural

${ }^{1}$ Extensive information about the parallel development of the literary Indian English narrative and Indian cinema can be found in Carmen Escobedo de Tapia \& Verónica Quevedo Revenga (2012). 
paradigm framed within the postcolonial has placed the cinema produced in India in a marginal space in the academic world with a generalized stereotypical vision of it, or just acknowledging the prestige of directors that convey an image of India that the coloniser recognizes as different so as to identify that formulaic 'idea of India'. As Bhabha states, the coloniser wants to feel identified within the stereotypical view of the colonised because it is precisely through this vision that it proves and secures its power over 'the others'.

This explains the first examples of Indian cinema, which were mere adaptations that mimicked the colonial image of India, based on Indian novels written by English writers like The Jewel in The Crown (1966) ${ }^{2}$ from Paul Scott's The Raj Quartet (1965-75), and E.M. Forster's A Passage to India (1924), which was adapted to the screen in 1984. A good example could be the analysis of the character McBryde and the episode of the Marabar caves in the second novel aforementioned. Bhabha explains how this character displays a sort of "oriental pathology" in his beliefs and scientifically justifies the lascivious and menacing condition of Indians. The stereotype of the lascivious orient, which Said extensively refers to in Orientalism (1978), vertebrates the narration of the episode of the Marabar Caves, which is accurately reflected in the film. Adela Quested accuses Dr. Aziz, an Indian, of having sexually abused her. According to Bhabha, this episode aims to reaffirm the British coloniser as white, European and English with the aim of condemning the oriental. Mc Bryde offers a negative characterisation of Dr Aziz as the common Indian, reader of pornography, sexually obsessed because of the climate and with an innate criminal nature. Though this interpretation could be discussed, through the example provided Bhabha links ambivalence and stereotype, and in this link lies the colonial fear towards the seditious, cruel, lascivious, and menacing native. These are the affective grounds on which the image of 'the other' is related to symbols like chaos and violence, and deploys the horror never explained nor understood in Joseph Contrad's Heart of Darkness (1899).

The truth is that the Indian cinema is as diverse and rich as the context in which it emerges. It is a space of ambivalence defined by an essentially Indian plural identity that has been conformed, as we shall see, throughout its development, which represents at the same time the change of the subcontinent in historical and social terms, thus justifying the need to consider the concepts of 'Nation', 'History' and 'Narration' that were firstly inferred through the thoughts of Bhabha in Nation and Narration (1990) and fully explained and illustrated by Priyampada Gopal in The Indian English Novel: Nation, History and Narration (2009).

The first examples of films related to Indian themes were undoubtedly tinted with what Bhabha termed 'mimicry', especially present in those directed and produced by the west and that made evident the urge of the coloniser to show the differences between colonised and coloniser so as to define their respective contrastive identities. The Indian becomes a menace for the British and produces

\footnotetext{
${ }^{2}$ I will refer to first edition dates so as to follow a chronological order within the article.
} 
the most shrilling nightmares about the colonised. This is explained in Bhabha's work "Of Mimicry and Man: The Ambivalence of Colonial Discourse" (1984). He suggests that mimicry, the same as stereotypes, is related with the need to define the colonial subject by asserting the similarities, but also all the differences, because mimicry implies at the same time a contradiction in which both the similar and the different would be included.

However, if we try to search for examples of colonial imitation in the cinema (the same as in literature) we should dive into the space that lies between the emulation and parody that defines the 'reformed civilized native', becoming almost a caricature, as is the case of Dr. Aziz in A Passage to India. This explains how mimicry becomes a menace, as Marlow in Heart of Darkness implies when, in front of a group of black people in Africa states: "The thought of their humanity -like yours - the thought of your remote kinship with the world and passionate uproar. Ugly" (51). The fear of the similar without being similar is here implied that leads to being rejected. It is what Eric Strokes (in Sen 2002) referred to as the "magnetic power of the periphery that distorts the natural development of the British character" (xxv). This explains the reason why the first examples of films about India where mainly based on British novels, as we have previously said, where the characters were meticulously defined and differentiated in terms of coloniser and colonised, and offered stereotypical images of not only the Indian subject, but also of the Indian landscape, like Walt Disney Productions animated film The Jungle Book (1967) or that of US director Steven Spielberg, Indiana Jones and the Doomed Temple (1984). Even adaptations of the first Indian novels written in English like M.R. Anand's Coolie (1936) or R.K. Narayan's The Guide (1958) show a total deviation of the true idea of India and the identity of the Indian subject trying to adapt the Indian reality to a western imaginary, proving the ambivalent space in which the origins of Indian cinema was placed.

As time went by, productions moved from the fear of showing India as a menacing colonised location to gradually exalt its true history and mythology. In this sense, it is worhtwhile mentioning historical films like Richard Attenborough's Gandhi (1982), or A Train to Pakistan (1998), directed by Pamela Rooks, a film adaptation of the novel by Khushwant Singh (1956) in which a beautiful love story in the midst of the horrible episode of Partition is narrated; or the animated film Sita Sings the Blues, directed by Nina Paley in 2008, where I find the influence of the traditional Sanskrit epic of The Ramayana in contemporary times.

These productions of international impact go parallel to Indian productions of Indian directors who have portrayed, sometimes very naturalistically, the image of India in its diversity: the pre-colonial and the colonial, the mythical past, the contemporary times, the modern megalopolis and the remotest villages lost in the vastness of rural India. Though the origins of cinema were linked to the coloniser, the Indian cinema would soon start its own development, offering the multiple representations of India, challenging a claim for independence that in little more than a century has produced films essentially Indian that conform it as a genre of its own.

I will offer a panoramic view of the development of the genre in relation with the threefold perspective -History, Nation and Narration- where it should be 
framed, because no idea of India would be faithful if it were not narrated in terms of the concept of a nation with its historical, social and cultural wealth. It is relevant to underline that the development of cinema in the subcontinent is of most interest to Postcolonial Studies, because it exemplifies what Mihir Bose (2007) considers:

one of the many cracks in the system of "apartheid" that the British colonizer imposed on India and that favoured the accessibility of the population to cultural products that in other colonized contexts like Africa, for instance was not possible until the achievment of Independence during the decade of the sixties and with a production and distribution strongly censored and controlled by the governments. $(40-41)$

This was not the case of India since it got hold of its own path and soon started a firm independent national industry, setting the basis of a system that in its most popular productions resembles Hollywood. Indian productions can be considered a true representation of the distinctive characteristics of the subcontinent, its multiple cultures, the symbiosis of the past and the present, the influence of the myths of The Mahabaratha and The Ramayana together with the social reality in-between wealth and poverty, fusing a cultural legacy of words, music, dance, and art in general. Accordingly, the development of cinema in India has not been homogeneous nor monolithic. It would be too reductionist to set a division like experimental films and popular films in regional languages (such as Bollywood, Tollywood...), since there is not just one popular cinema, but as many as vernacular languages exist. ${ }^{3}$

Different periods can be distinguished that are related to issues like the exhibition and reception of films. The relationship between history-nation-narration is the frame for that development, since it equally represents the diverse social conditions that characterised the subcontinent all through the twentieth and twentyfirst centuries. During the period of silent cinema, foreign films were frequently projected in the most luxurious cinemas of the cities. Actors like Charles Chaplin, Buster Keaton or Harold Lloyd were on the screens for the enjoyment of the wealthy and upper castes of the Indian society of the times. On the other hand, films in Hindi (produced in the region of Mumbai, with a specific economic development and consumption of cinemas) would be mostly projected in the marginal cinemas of the cities. These first examples included a high level of acrobatic content, and they were exhibited in the open air, both in the cities and in villages. Sometimes they included drama representations. An example of this stage would be the showman Abdullaly Esoofally, who brought cinema to Birmania, Singapur and Indonesia, as well as to most parts of india. He would travel with a projector, a tent and a portable screen from 1901 to 1907. Later some national companies would buy the cinemas

${ }^{3}$ I should refer here to the work and research on Indian cinema by Rachel Dwyer and Vijay Mishra, which widely contribute to the knowledge on the subject. 
located in the wealthiest parts of the cities to offer entertainment for the upper castes; this way, the cinema would gradually become a national means of entertainment.

Likewise, its progress reveals an evolution of tastes and aesthetics. In the period of silent cinema, it was frequent to find mere imitations of western productions. As the genre evolved, and since the introduction of sound, an eminently Indian aesthetics with a true independent identity was conformed, where the presence of music and dance were and are inherent elements of the filmic narrative. All these elements caused a fragmentation of the main narrative and, in turn, would cause a dislocation on the western spectator, but in the case of Indian cinema they become natural, showing the great variety of ingredients that conform Bollywood films and that represent the true nature of the Indian context. The term Bollywood comes from the fusion between Bombay and Hollywood as major representative of the cinematographic industry of the west. This is of essential interest because it proves the rethoric and dialectic implied between the west and the east (the coloniser and the colonised), between the excessive mercantilism of the west and a country fully characterised by spiritualism, or the confrontation between First World cinema and Third World cinema. These oppositions are, as Bhabha (1994) argued, related to the need of the west to feel different from the east, but also to show the need of the colonised to redefine their identity in terms of that ambivalent space that I mentioned at the beginning of this article.

\section{ORIGINS: SILENT CINEMA}

How did cinema reach India? Globally, it was in the Grand Café in the Boulevard des Capucines in Paris that the first film was projected in December 1895. Few months later, in July 1896, a selected audience at the Watson's Hotel in Bombay enjoyed the same repertoire that the Lumière Brothers introduced in France. Maurice Sestier, who oversaw taking the pioneer films to Australia, had to stop at Bombay. It was then that cinema starts its evolution in India as a popular entertainment for an increasingly urban population. For a time, only foreign films were projected, in connection with the literary sphere and related to the feeling of imitation implied in the concept of mimicry already explained. Soon the process of inscribing their own identity in the cinematographic narrative moved pioneering Indian directors to claim for an independence. Save Dada (Harischandra Sakharam Bhatavdekar) was a photographer who recorded some silent films with a camera he had imported from London, and he projected them in the open air. His most acknowledged production was Wrestler (1899), where he told the story of two famous Indian wrestlers: Pundalik Dada and Krishna Nahvi. Other examples like A Man and his Monkeys (1899) or Local Scenes: Landing of Sir M.M. Bhownuggre (1901), showed a local character. During this first period it should also be highlighted the production of Hiralal Sen and his brother Motilal in Calcutta. They produced a version of Alibaba and the Forty Thieves (1899) which has been lost, and they filmed the first commercials. It would be in 1912 when Pundalik, the first film of fiction with an authentic Indian theme, was produced by Ramchandra Gopal Torney; it was based on the life of a saint. 
The First World War gave a great impulse to the cinematographic industry in India. This reduced the possibility to import foreign films. The industrialization of the country attracted many people into the cities who were eager to enjoy new ways of entertainment and were in search of local images that the cinema could offer. Big entepreneurs decided to invest in this new means of expression. There was a move from a handicraft production to the creation of the first studios in the twenties. These were small, but they already had two or three rooms with curtains to blur the light, as well as a separate laboratory for post-production tasks.

Throughout the twentieth century there was an increase from a $15 \%$ of the market that Indian productions could control to absorbe the majority of the showtimes in the local cinemas in the forties. The Indian cinema that was aimed for an exclusive Indian audience, though more expensive, was notably more profitable; this would contrast with the marketing rate that national cinemas could achieve in the rest of the world at that time. After Independence, it reached unbeattable rates: from 251 productions in 195 to 300 in 1960, 400 in the seventies, 719 in 1980, and, three years later, 763. It is currently estimated that the annual production of Indian cinema has risen to 900 films. From the beginning of the twentieth century up to the contemporary times the Indian cinema production has increased and has gained international recognition and impact (Armes 117).

Dadasahed Dhundiraj Govind Phalke (1870-1944) is considered the father of Indian Cinema. He came from a family of intellectuals and, since he was very young, he showed great photographic and creative talent. Inspired by The Life of Christ (1910), he made films about Indian deities like Rama and Krishna. He lived in London, were he learnt more elaborate film techniques, and when he returned to India he produced the first experimental film, Raja Harishchandra (1912), which showed static shots and an episodic structure, being a clear referent for Satyajit Ray. Phalke would set the basis of 'the studio system'. His home was turned into a studio; its surroundings served the purpose to recreate very diverse scenarios. $\mathrm{He}$ is considered a master of special effects and he expertly used the wealth of Indian mythology. Examples are Dahan (1917), inspired in The Ramayana, Mohini Bhasmasur (1914), Shiri Krishna Janma (1918) and Kalia Mardan (1919). He enthused many entepreneurs in Bombay who invested greatly in Indian cinema. These productions run parallel to the historical moments where they were framed. These were the times when Gandhi would start his political and social action in India and the winds of a nationalistic upsurge began to blow, favouring the role of both literature and cinema as decolonising tools claiming to recover the true identity of a country that had been subject to British imperialism since the nineteenth century.

Another influential figure of the 1920s was the Parsi director Jamshedi Framji Madan, who would contribute to the development of the cinema by incorporating many traditions from the Parsi theatre, like the historical romance melodrama and mythology. His productions were mainly foreign titles and noticeably of a European character so as to attract the upper castes of the society. Those were high quality productions in which Hindi mythology and show would intermingle. It was the first time a woman was enrolled as an actress, Patience Copper, of Anglo-Indian origin. 
A good example of Madan's art would be Nala and Damayanti (1920), based on The Mahabharata, where he tried Hollywood lights effects and techniques. In 1919 he founded Madan Theatres Limited, a company that had great influence during the twenties and the thirties. Later, his son would widen the themes used, including from popular stories of Arab origin to contemporary love stories, as is the case of Satyawadi Raja Harishchandra (1931).

Another significant name of the time was Diren Ganguly (1893-1978), born in Calcutta, who wrote a script in 1920 where the Indians who had lived in England for a time were satirised. He criticised their pseudo British ways with which they would try to mimic Europeans, as well as the conservatism of some Indians. An example could be Bhelta Pherot (Return to England) (1921), which was produced by the newly found Indo-British Film Company.

Other relevant figures during this period that would set the basis of its evolution were Debaki Kumar Bose (1888-1975), who was a fanatic of the theme of love, as reflected in the script for Flames of Flesh (1930), and Chadulal Shah (18981975), who produced films with English titles, like Typist Girls (1926), Educated Wife (1935), and his great success, Gunsandari (Why husbands go Astray) (1927). In this last film, he tackled for the first time the social theme in Indian films in which the roles of men and women were equalled.

In the beginning of the twentieth century, Indian cinema clearly illustrated the historical moment the nation was undergoing. The same as in the literary sphere, the basis of a later development was set. The clash between the Indian and British cultures was made evident through the films produced, where the mythological past was used in an attempt to reject the coloniser and as a claim to achieve a new identity. The thematic trends proved the criticism that was originated from the nationalist rise that was backed up by Mahatma Gandhi as a political and social leader, and by writers like Raja Rammohan Roy and Rabindranath Tagore in his work Nationalism (1917). Social themes appeared on the screen, showing a stern reaction and criticism not only towards the coloniser but also the colonised. Indian intellectuals started to take conscience of the many consequences the colonisation had brought into the country, and filmic and literary narrations showed the transference from the colonial to the postcolonial.

\section{THE ARRIVAL OF SOUND}

The arrival of sound caused a great impact on Indian cinema. The 1930s could be considered a landmark in the evolution of both literature and cinema in India. If it is true that the arrival of sound allowed for the improvement of films, with the inclusion of musical shows full of fantasy mixed with simple technique, it also originated a complex situation. Being a country where there was a great illiteracy rate and at the same time characterised by polyglossia, the films had to be subtitled in several languages: Hindi, Telugu, Tamil and Marathi. In some cases there were even two shifts for actors of different languages so as to maintain the same stage and musical shows. 
Two trends were originated; on the one hand, the so called 'All-India Movie', which was produced in Bombay with great budgets and aimed at an Indian audience, and, on the other hand, local productions in other vernacular languages (Armes 110). One of the main directors during this period was Vandruke Shantaram (19011990), who produced films with mythological themes in Hindi and Marathi, like Ayodhyecha Raja (The King of Ayoda) (1932) or Amor Jyoti (Eternal Flame) (1936), in which the role of the woman is emphasised; other films deployed social themes in which social conventions were analysed, while others tackled the Hindu-Muslin confrontation, and religious radicalisms are examined in films like Amritmantha (1934).

The Gandhian Era (1930-1947) set the basis of Modern India in many spheres of life. It was a time of social turmoil that triggered a revolutionary trend in artistic forms like the literature and the cinema of the period, which set the pave for independence in search of a new identity that would emerge from the need for self and collective reaffirmation in the transition to the postcolonial. B.N. Sircar and P.C. Barau (1903-1951) worked together in the production of films which would try to recover the myths of the past in terms with this need to claim for an authentic Indian identity. Devdas (1935) narrates the story of love between Krishna and Radha. It is still the more covered in the history of Indian cinema. ${ }^{4}$ This first version proved the art of the directors who managed to turn social themes into romantic melodramas together with the most advanced techniques of the times.

The Bombay Talkies Studios, one of the most important film companies was founded by Himansu Rai and his wife Devika Rani in 1935. Many important actors like Raj Kapoor were trained in the company. The west provided new techniques that would contribute to give shape to films that represented the religious panorama of India. Soon the social themes actually became social criticism, representing the idea of a hybrid India in search of its identity within the ambivalent space that the postcolonial period had created in its transformation from the colonial. An example could be Achhut Kanya (The Untouchable Girl) (1936) and Ashok Kumar, the so-called sponsor of Indian cinema and the protagonist in the film, which tells the love story between an untouchable woman and an upper-caste man, mirroring this historical moment when Gandhi was fighting for radical changes in certain social traditions. The theme of novels like Untouchable (1935) or Coolie (1936) by M.R. Anand evince the parallel development of both narratives in consonance with the historical development of the Indian nation, gathering, once more, history, nation and narration. In this period the arrival of playback in 1937 reaffirmed the musical character of the Indian cinema as one of its most significant characteristics since it allowed the actors and actresses not to be necessarily singers.

\footnotetext{
${ }^{4}$ Later versions of the film were released in 1955 and 2002.
} 
Independence in 1947, intellectuals and activists like Gandhi or Rabindranath Tagore and Jawarhalal Nehru, among others, achieved their dream of a free India, but the aftermath was not what they expected. The social atmosphere was agitated by the continuous Hindu-Muslin confrontations ultimately causing Partition, one of the most tragic episodes in the history of the subcontinent, which led to the wreckage of Gandhi's fight during the first half of the twentieth century. India was inmersed in social chaos that ended up with Gandhi's murder in 1948. Democracy was established, but Indian identity had been shaken to the roots and there was the need to restore the new 'idea of India' as a free country. Actually, democracy in India was influenced by the feeling of a united nation provided the impulse for achieving Independence had been shuttered, but it was time to recover the Indian self by restoring the past in order to explain the chaotic present. In this historical framework, the experimental cinema and Bollywood appear. Up to that moment, as formerly stated, cinema was mainly an entertainment mainly based on fantasy and rethoric, but after the achievement of Independence the social themes became the main tool to fight the reality of the moment: the power of control, hunger, and the change of moral values that appear with the new postcolonial identity of the Indian subcontinent after 1947. The concept of nation acquired relevant meanings frequently contrasting good and evil or the urban life as the locus of western materialism full of negative connotations as opossed to the essence of the 'Indian self.'

The 'Golden Age' of the Indian cinema comes with Satyajit Ray (1921-1992) as an icon of the experimental cinema. He is the most internationally acknowledged Indian film director. His films depict a great variety of the Indian society of the nineteenth and twentieth centuries in comedies like Parash Pathar (The Philosopher's Stone) (1957), romances and musicals like Goopy Gyne Bagha Byne (The Adventures of Gopy and Bagha) (1969), documentaries and even adaptations of Rabindranath Tagore's works. His creativity represents an intellectual fusion between the western and eastern artistic filmic forms. He analysed the philosophical pillars of the Indian culture while introducing the concepts of democracy, liberalism and social and gender equality in Indian films (Armes 231). He is best known for his Trilogy of Apu: Pather Panchali (1955), Aparajito (1956) and Apur Sansar (1959). The trilogy enhanced the contrast between modernity and tradition and showed how this affects the son of a Brahman growing into adulthood. Later, his films explore orthodox Hindu values and analyse deeply the psychology of the characters; rural India is an important aspect of his films, together with fantasy, humour and women issues.

Ray's art greatly differs from Indian popular cinema, as Armes (1987) argues, because of its peculiar narrative structures and concentration on details based on western techniques, as well as his concept of rhythm and the soundtracks he himself composed. Music has a cathartic purpose in his films, but it never overcomes the power of images. Ray has been considered a master because of the depiction of his characters, authentically human and vulnerable, absolutely accesible for the audience. This "compassionate image" (8) he offers, according to John Kenneth Muir (2006), makes Ray a world reference as a film director. 
The aesthetics of Bollywood would be of great contrast. Significant directors were Bimal Roy, Guru Dutt or Raj Kapoor, but Mehboob Khan, of Muslin origin, should be highlighted. He produced one of the most influential Indian films: Mother India (1957). It portrays the fight of a mother who has to kill her own son to save the daughters of the community. The social reality of the time -contrary to many Bollywood romances located in the rural past- incorporates elements of modern India. It tells the story of an old mother who foresees the future of a nation. It was the first Indian film submitted for the Academy Award for Best Foreign Language Film in 1958, and it is probably one of the most accredited both in India and abroad. Its musical shows gained popular success. Full of Indian symbolism, the film belongs to a popular tradition also present in other artisitic fields like painting and literature, where the nation is represented as a woman, specifically a mother. This is a clear symbol of an anti-imperialistic and nationalistic movement that used the image of a woman as the map of the Peninsula. In literature, the novel Anandamath (1882) by Bankim Chandra Chatterjee, represented the Indian nation as Goddess Durga, killing demons as she rides a lion. In Mother India, the strength and courage of the protagonist, Radha, is emphasised over the vulnerability of her husband, who loses his arms and, consequently in symbolic terms, his masculinity.

If the two representative trends of this period are compared through Ray's trilogy and Mother India, it can be concluded that they entail similar thematic elements. Both tell the story of a poor family that has to overcome different ordeals that increase their poverty. In both narratives the audience is aware of the force of nature through torrential rains that destroy their homes and children who die of hunger or because of natural disasters. Both portray costumbrist scenes like festivals and weddings or daily work. In Mother India these are the excuse to include dances, music and songs that contribute to the narrative. Ray offers sober images, emphasising more static and general shots between episodes and avoiding digression from the main narrative. Mother India stands as a paradigm of how popular cinema is influenced by popular dramatic forms, among others.

By the end of the 1950s, popular cinema in India had already settled. In 1969 Amitabah Bachban arrived in Bombay and he changed the history of Indian cinema. His film Zanjeer (Shackles) (1973) was a success and represents the general social discontent with the government of those times, criticising corruption and bureaucracy. It starts the police genre, where action would be given more relevance than musical shows and where the protagonist turns from a traditional hero into and antihero who feels responsible to fight the underworld of corruption.

During the 1960s and the 1970s the evolution of the Indian cinema would show the 'idea of a modern India' with the fusion of western and Indian elements. Gopaldas Parmanand Sippyappears with his film Sholay (1975) gives birth to the 'masala curry western', a kind of Indian western which mixed dance, music, songs, and features of the Hindi film with the typical ingredients of westerns.

The decade of the 1980s was not very productive for the cinema globally due to the appearance of television and the video. In India, the audience preferred to stay at home rather than risk their health in theatres or cinemas that were considered 
infectious focuses. Piracy seriously damaged the film industry too, which would witness the emergence of big complexes and cineplexes.

At the beginning of the twenty-first century, films like Devdas (2002), directed by Sanjai Leela Bhansali, together with actress Aishwarya Rai, helped to make Bollywood profitable again. It is worthwhile mentioning Lagaan (2001), starred by Aaamir Khan. This film presents a simple argument with the contrast between two cultures: the Indian and the British. The film takes place in the Victorian period in line with the fluidity of a neo-Victorian wave that also takes place in literature (Llewellyn 2010). The high budget allowed for high-quality techniques and dances perfectly synchronized, showing a hybrid style. The final outcome was a natural presentation of the argument that made the film a great success both in India and the west.

\section{CONTEMPORARY CINEMA}

Nowadays, films gather the diversity of India through the influence of the classical epics of Sanskrit with recurrent themes like maternity and revenge or trying to maintain the traditional values that conformed the social hyerarchy of India. This influence is also felt in the narrative structure of films, often with digressions that make Indian films too long for the western audience. The influence of theatrical forms is also present, with an episodic structure, an emphasis on performance over realism and the introductions of traditional music like the sangeetas, a mixture of instrumental music, song, dance and humour, elements that come from the classical theatre and the Parsi theatre. The influence of the west is also felt in the musical parts of the films. These are recorded from different angles, with zooms or quick movements that oscillate at the rhythm of the music, simulating western musical videos and breaking with the dramatic elements of traditional Indian films.

More modern perspectives like the New Indian Cinema appear which aim to break with the traditional Bollywoodian aesthetics. The themes show the idea of a contemporary India' where the west has been assimilated, but the tradition and the true essence of India as a diverse multilingual country is evident. Films are recorded in English, but also use other languages and illustrate the contemporary Indian middle class. Examples can be Dev Benegal, who produced English, August (1994), an adaptation of a novel by Upamanyu Chatterjee.

Among more globalising perspectives, Indian directors like Pradip Krishen and Aparna Sen (who is also an actress) can be mentioned. They aim to represent the cultural contrast and generation gap in modern India, and they express the multiple ambivalent emotion of diasporic souls with the inclusion of various tongues and different perspectives of the world. During the first part of the twenty-first century, Bollywood seems to have turned to English and has done away with its dependence on music and dance in favour of more realistic and less tragic stories. However, English and Hindi -Hinglish- fuse together in the dialogues as a proof of the reality of contemporary India, which has come to integrate the Indian self and the inheritance of the British colonisation. This encounter has conformed the 
'idea of India today' as a transcultural society, that at the same time keeps to the essence of a diverse India with a national sense that gathers the plural identities of the subcontinent, which has turned glocal too.

This historical, social and cultural panorama frames the stories of contemporary directors. An example of New Milennium Cinema is Zindagi $\mathrm{Na}$ Milegi Dobara (No Second Chance), directed by Zoya Akhtar in 2011. Its argument deploys the cultural hybridism and the importance of money in the contemporary global scenario, the strong influence of technology among the young generations, the change of traditional ways of living and social relationships, etc. Its main song, "Señorita", was performed by a Spanish flamenco singer, soon became a great global success. We can here establish a parallel with novels like The White Tiger (2008) by Aravind Adiga, which has recently been adapted as a film for Netflix (2021). The social image of a new India is clearly represented with stern irony and criticism, with the western evils of materialism and consummerism especially affecting the new generations. The same idea was previously portrayed in the novel $Q \& A$ : $A$ Novel (2005) by Vikas Swarup, which inspired the film Slumdog Millionaire (2008), directed by Danny Boyle, where we can find the reminiscence of a Bollywoodian spirit in the final musical performance, being at the same time an example of the transcultural essence of contemporary India.

During this period, the strength of Bollywood music mixes with a narrative rhythm that comes from the west. The concept of a dislocated home, global economy, and the new transcultural identity are mainly reflected in the films produced by best known diasporic directors like Mira Nair, Deepa Mehta and Gurinder Chadha who were born in India, but now live in the US, UK or Canada. They portray the Indian life and customs as well as use more universal and western themes and aesthetics. These directors often illustrate the life of Indian inmigrants in western contexts that represent the double soul of the inmigrant, parallel to the hybrid Indian self. Their films mainly keep to a similar aesthetics, and they use imagined colourful, often symbolic scenes. Music and dance with clear Indian reminiscence gain importance, but contrary to popular cinema, they also use realism in the form of a party or a quiz contest, as spiritual cathartic moments in the film.

Gurinder Chadha tackles in Bend it Like Beckham (2002) issues related to gender and family conflicts, urging the Indian women who live in the west to make their own decisions and fight for their own dreams. Bride and Prejudice (2004), adapted from Jane Austen's Pride and Prejudice (1813), stands as an example of fashionable versions of the Regency period in the filmic narrative. She aims to show that not all weddings are arranged in India and true love can win. This is also one of the themes in the novel A Suitable Boy (1993) by Vikram Seth, recently adapted as a Netflix series (2020), which emphasises the force of love against deeply-rooted social and religious traditions, as well as the endemic conflict between Hindus and Muslins in a contemporary society that inevitably assimilates the past and the present. Social criticism is part of Deepa Mehta's narrative in her trilogy Earth (1998), Fire (1996) and Water (2005). The first is one of the most beautiful films on the theme of love during Partition; the second deals with homosexual love between two women; and the last one criticises the strict situation imposed on widows in India, especially in 
today's rural areas. The three films stand as examples of the social critical insight that characterises Mehta's productions.

\section{CONCLUSION}

Indian cinema proves to be an all-encompassing source of inspiration to exemplify the strong link suggested by the threefold perspective History, Nation and Narration. Through its fruitful evolution, it seems to have aimed at depicting an authentic 'idea of India', free from a passionate exaltation of the contextual stereotypical elements that might have always been attractive for a western audience. Indian film directors offer a caleidoscopic and unstereotypical representation of India. The perspective that they include in their productions provides a critical insight to 'the idea of India', which in its historical, social and cultural progress has come to be what it is nowadays. They have managed to be faithful to themes that are inherent to a diverse culture that has moved from the past to the contemporary and displays a plural identity that has resulted from the intermingling of an ancient civilization and a history of invasions, especially the western influence inherited after two hundred years of British colonisation.

There are positive and negative implications to this, but the truth is that the historical development of the subcontinent in the twentieth and twenty-first centuries has allowed Indian cinema (and literature) to acquire international recognition, becoming a genre of its own far from the mimicry and liminality proclaimed by Bhabha. The evolution that has taken place up to the contemporary times also enhances the importance of the concept of time, where the past and the present of a nation fuse together, so as to offer an 'idea of a contemporary India' which, as has been proved, reaffirms the wealth of the hybrid diversity that conforms the ambivalent context where cinematographic (and literary) narratives emerge. 


\section{WORKS CITED}

Adiga, Aravind. The White Tiger. London Atlantic Books, 2008.

Anand, Mulk Raj. Coolie. Gulab Nazirani, 1981 [1936].

Anand, Mulk Raj. Untouchable. Penguin, 2001 [1936].

Armes. Roy. Third World Film Making and the West. University of California Press, 1987.

Austen, Jane. Pride and Prejudice. Penguin English Library, 2012 [1813].

Chatterjee, Bankim Chandra. Anandamath or The Sacred Brotherhood. Oxford University Press, 2005[1882].

Conrad, Joseph. Heart of Darkness. Ed. Paul B. Armstrong. Norton Critical Editions, 2016[1899].

Внавна, Homi K. The Location of Culture. Routledge, 1994.

Bнавна, Homi K. "Of Mimicry and Man: The Ambivalence of Colonial Discourse". Discipleship: A Special Issue on Psychoanalysis 28 (1984): 125-133. https://doi.org/10.2307/778467.

Escobedo de Tapia, Carmen \& Verónica Quevedo Revenga, Eds. Narrativa y cine de La India en lengua inglesa: una aproximación para la Era Global. Bohodón Ediciones, 2012.

Forster, E.M. A Passage to India. Penguin Essentials, 2015 [1924].

Gopal, Priyamvada. The Indian English Novel: Nation, History and Narration. Oxford University Press, 2009.

Heilmann, Ann \& Mark Llewellyn, Eds. Neo-Victorianism. The Victorians in the Twenty-First Century, 1999-2009. Palgrave Macmillan, 2010.

Minir, Bose. Bollywood. A History. Tempus, 2007.

Muir, John K. Mercy in her Eyes. The fims of Mira Nair. Applause Books, 2006.

Kilkani, Sunil. The Idea of India. Penguin Books, 1997.

Narayan, R.K. The Guide. 1958. Penguin, 2006.

SaId, Edward. Orientalism. Penguin Modern Classics, 2003 [1978].

Scotт, Paul. The Jewel in The Crown. (Raj Quartet 1). Arrow, 1996 [1966].

SEn, Sudipta. A Distant Sovereignty: National Imperialism and the Origins of British India. Routledge, 2002.

Seth, Vikram. A Suitable Boy. Phoenix, 1993.

SingH, Khushwant. Train to Pakistan. Chatto \& Windus, 1956.

Swarup, Vikas. Q \& A: A Novel. Scribner, 2005.

TAgore, Rabindranath. Nationalism. MacMillan \& Co Ltd., 1917.

\section{FiLMS CITED (IN CHRONOLOGICAL ORDER)}

A Man and his Monkeys (1899)

Alibaba and the Forty Thieves (1899)

Wrestler (1899)

Local Scenes: Landing of Sir M.M. Bhownuggre (1901)

The Life of Christ (1910) 
Raja Harishchandra (1912)

Pundalik (1912)

The Ramayana, Mohini Bhasmasur (1914)

Dahan (1917)

Shiri Krishna Janma (1918)

Kalia Mardan (1919)

Nala and Damayamti (1920)

Bhelta Pherot (Return to England) (1921)

Typist Girls (1926)

Gunsandari (Why husnbands go Astray) (1927)

Flames of Flesh (1930)

Satyawadi Raja Harishchandra (1931)

Ayodhyecha Raja (The King of Ayoda) (1932)

Amritmantha (1934)

Educated Wife (1935)

Amor Jyoti (Eternal Flame) (1936)

Achhut Kanya (The Untouchable Girl) (1936)

Trilogy of Apu: Pather Panchali (1955), Aparajito (1956) and Apur Sansar (1959)

Parash Pathar (The Philosopher's Stone) (1957)

Mother India (1957)

The Jungle Book (1967)

Goopy Gyne Bagha Byne (The Adventures of Gopy and Bagha) (1969)

Zanjeer (1973)

Sholay (1975)

Gandhi (1982)

Indiana Jones and the Doomed Temple (1984)

A Train to Pakistan (1998)

Earth (1998)

English, August (1994)

Fire (1996)

Lagaan (2001)

Devdas (2002)

Bend it Like Beckham (2002)

Bride and Prejudice (2004)

Water (2005)

Sita Sings the Blues, 2008.

Slumdog Millionaire (2008)

Zindagi Na Milegi Dobara (No Second Chance) (2011)

A Suitable Boy (Netflix Series) (2020)

The White Tiger (Netflix) (2021) 